\title{
Potent Antiulcerogenic Activity of Methanol Extract of Cissus quadrangularis by Antioxidative Mechanism
}

\author{
Mallika Jainu and C.S. Shyamala Devi* \\ Department of Biochemistry and Molecular Biology, University of Madras, Guindy Campus, Chennai 600 025, \\ India
}

Received 8 May, 2003; Accepted 14 October, 2003

\begin{abstract}
Summary Oxidative stress is considered to be one of the important etiological factors in various diseases including gastric ulcers. The mechanism of aspirin induced gastric lesion is mediated through lipid peroxidation. The effects of Cissus quadrangularis extract on aspirininduced ulceration in rats with respect to its antioxidant status, lipid peroxidation, quantity of mucus and alkaline phosphatase and myeloperoxidase (MPO) activities was estimated. Cissus quadrangularis facilitated the healing of experimental gastric ulcer by increased mucus content, antioxidant defense enzyme activity and decreased MPO activity and lipid peroxides levels in the gastric mucosa. These results indicate that Cissus quadrangularis extract protects against aspirin-induced gastric mucosal lesions in rats possibly through its antioxidative action.
\end{abstract}

Key Words: aspirin, Cissus quadrangularis, gastric mucosal lesion, antioxidant status

\section{Introduction}

Free radicals have aroused significant interest among scientists in the past decade [1]. Oxygenderived free radicals, which play an important role in the pathogenesis of peptic ulcer apart from the interactive processes, like many other tissue degenerative situations [2]. In the recent years there has been considerable interest in natural products with antioxidants of plant origin, which have been identified and used as effective protective agents against oxidative stress [3].

Most of the synthetic compounds given for gastric ulcer contribute for various undesirable side effects or drug interaction [4]. There are many antiulcerogenic plants, which might provide useful sources for the development of drugs, in the treatment of ulcer [5]. Cissus quadrangularis Linn. (Vitaceae) exhibits wide range of beneficial and pharmacological proper-

\footnotetext{
* To whom correspondence should be addressed.

Tel: +044-24412575

E-mail: cssdevi@yahoo.com
}

ties. In Indian traditional medicine, the plant has also been used to cure dyspepsia, eye disease, piles, fracture swelling, wounds, burns, spleen disorder, asthma, 'vatta' and 'kapha' conditions [6]. The antiulcerogenic effect of Cissus quadrangularis against gastric ulcer model in rats has been reported [7]. Although Cissus quadrangularis has been investigated for its fracture healing [8] and analgesic properties [9], detailed studies on its antioxidative potential and lipid peroxidation level in ulcerated rat are still lacking. Among the various factors that lead to initiation of peptic ulcer, alcohol abuse, acute and chronic stress and prolonged use of non-steroidal inflammatory drug (NSAID) are the major causative ones, apart from the much controversial Helicobacter pylori infection [10]. Reactive oxygen species (ROS) may play an important role in the pathophysiology of acute ulceration induced by NSAIDs, the treatment with potent scavengers of free radicals conferred mucosal protection, and significantly reduced the severity of these lesions [11]. Further, we thought that it would be worthwhile to evaluate the antiulcer effect of Cissus quadrangularis against aspirininduced ulcer, in terms of its antioxidative activity. 


\section{Materials and Methods}

\section{Plant material}

Stem part of Cissus quadrangularis was collected from Native Care and Cure Centre, India. The fresh air-dried materials were powdered in a mechanical grinder. Crude powder was then soaked in methanol with intermittent shaking. The filtrate was collected and used for extraction using Soxhlet apparatus. The residual solvent was removed under vacuum drier and the solid brown mass obtained was stored at $-4^{\circ} \mathrm{C}$ for further use. The extract was dissolved in distilled water and used in the present study.

\section{Animals}

Male albino rats of weight $175-200 \mathrm{~g}$ were purchased from Tamil Nadu University of Veterinary and Animal Sciences, Chennai. The animals were housed in polypropylene cages maintained at $27 \pm 2^{\circ} \mathrm{C}$ in temperature, $55 \%$ in humidity, and a 12 $\mathrm{h}$ light $/ 12-\mathrm{h}$ dark cycle. They were fed standard laboratory chow (Hindustan Lever Foods, Bangalore, India) and provided with water ad libitum. The study was conducted after obtaining animal ethical committee clearance (360/01/a/CPSEA dated 19-12001).

\section{Dosage fixation}

Normal rats were treated with 250, 500, and $1,000 \mathrm{mg} / \mathrm{kg}$ of Cissus quadrangularis extract respectively for 3,7 and 15 days and $1 \mathrm{~h}$ prior to ulcer induction. On $3 \mathrm{rd}, 7$ th and 15 th day the rats were challenged with a single dose of $400 \mathrm{mg} / \mathrm{kg}$ of aspirin administered orally. The rats were killed after $4 \mathrm{~h}$ post-aspirin exposure for determination of gastric lesions in gastric glandular portion under microscope. The area of mucosal damage of glandular stomach was calculated in square $\mathrm{mm}$ [12]. This preliminary study suggested that Cissus quadrangularis at a dose of $500 \mathrm{mg} / \mathrm{kg}$ given for 15 days appear to be more effective in preventing aspirin-induced gastric lesions. Therefore, this dose was chosen as optimum dosage for further studies.

\section{Experimental methods}

Rats were divided into 4 groups of 6 animals each as follows: Animals were fasted for $24 \mathrm{~h}$ provided with water ad libitum.

Group I: Normal control

Group II: Rats given oral administration of aspi$\operatorname{rin}(400 \mathrm{mg} / \mathrm{kg})$
Group III: Rats given Cissus quadrangularis extract $(500 \mathrm{mg} / \mathrm{kg} /$ day, orally) for 15 days

Group IV: Pretreatment with Cissus quadrangularis $(500 \mathrm{mg} / \mathrm{kg} / \mathrm{day}$ orally for 15 days) and then oral administration of aspirin $(400 \mathrm{mg} / \mathrm{kg})$

For estimation of biochemical parameters, gastric mucosal tissue was taken from the antral portion of the stomach. The surface gastric mucus was removed by scraping the mucus with glass slide and it was immediately homogenized in $4 \mathrm{ml}$ of distilled water. The mucus weight (mg) was obtained from the difference between the weight of homogenate and that of water [13]. Total proteins were determined by the method of Lowry et al. [14]. Alkaline phosphatase (ALP) activity was measured using the method of Kind and King [15]. The changes in the activities of gastric mucosal myeloperoxidase (MPO) an index of tissue neutrophil infiltration were measured [16]. Lipid peroxidation was estimated in terms of thiobarbituric acid reactive substances (TBARS), using malondialdehyde (MDA) [17] as standard. Superoxide dismutase (SOD) and catalase (CAT) activities were determined by the method of Misra and Fridovich [18] and Luck [19], respectively. Reduced glutathione (GSH) content was determined after deproteinization by the method of Beautler and Kelley [20]. Glutathione peroxidase (GPX) and glutathione-S-transferase (GST) were assayed by the method of Paglia and Valentaina [21] and Habig et al. [22].

\section{Statistical analysis}

The results were presented as the mean \pm SD. Student's $t$-test was used to analyze statistical significance in various groups of animals.

\section{Results}

The methanolic extract of Cissus quadrangularis exhibited significant healing effect on NSAIDinduced gastric ulcer, as evidenced from various biochemical parameters. Oral administration of the extract showed reduction in the ulcer index and healed at a faster rate with in 15 days.

Figure 1 shows the effect of Cissus quadrangularis on mucus content, MPO and ALP activities in aspirin-induced ulcer. Pretreatment with Cissus quadrangularis significantly $(p<0.001)$ enhanced the mucus content in ulcer induced rats and prevented the increase in gastric mucosal MPO and ALP activities. 


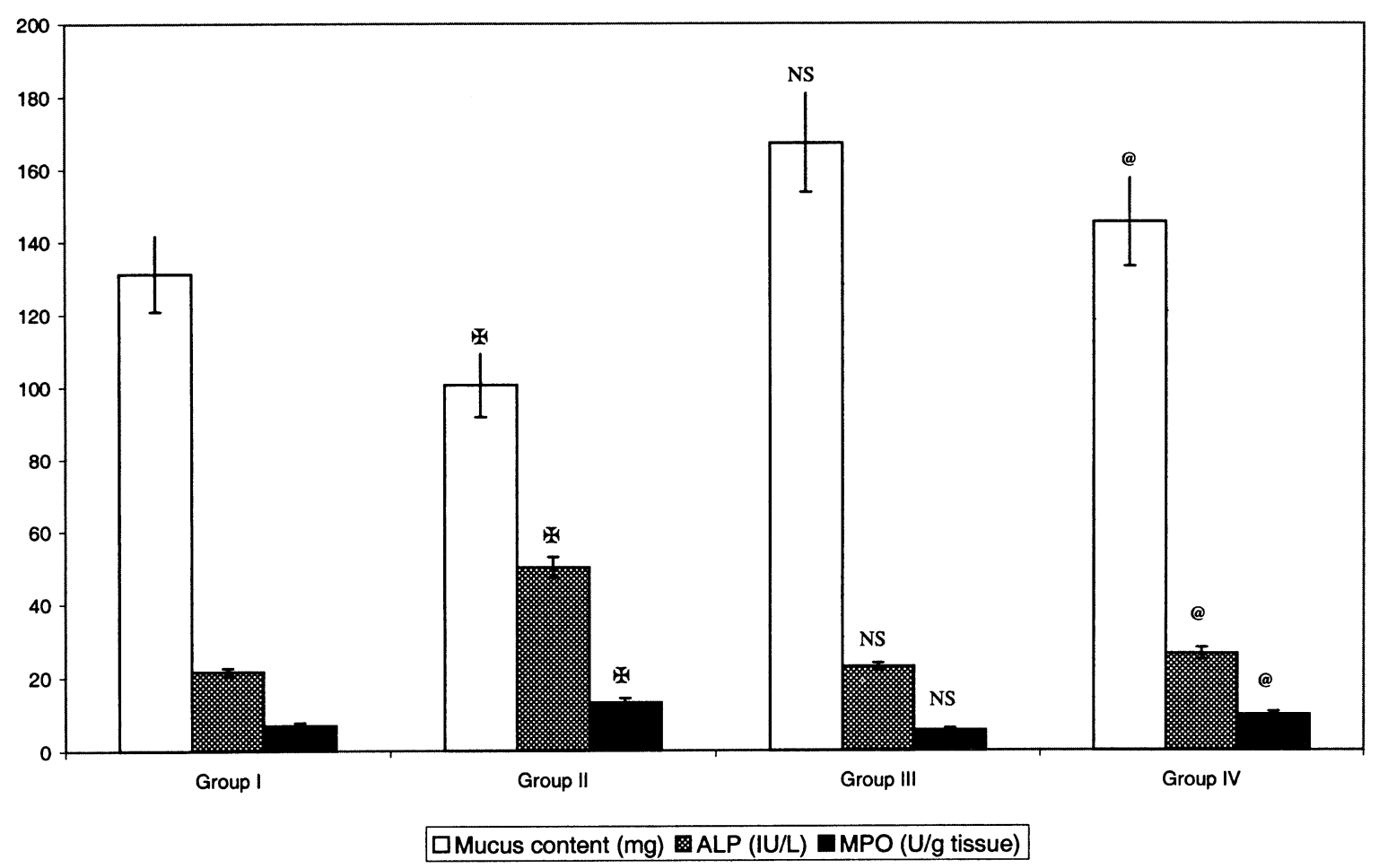

Fig. 1. Effect of Cissus quadrangularis on gastric mucus content, alkaline phosphatase and myloperoxidase activity in experimental groups. Group I, normal control; Group II, aspirin induced; Group III, Cissus quadrangularis treated; Group IV, Cissus quadrangularis + aspirin. Values are expressed as mean \pm SD for 6 animals in each group. $p<0.001$ as compared with Group I; ${ }^{{ }} p<0.001$ as compared with Group II; NS, non-significant as compared with Group I.

Table 1. Effect of Cissus quadrangularis on the antioxidative status in the gastric mucosa of experimental groups.

\begin{tabular}{lcccc}
\hline \multicolumn{1}{c}{ Parameters } & $\begin{array}{c}\text { Group I } \\
\text { Control }\end{array}$ & $\begin{array}{c}\text { Group II } \\
\text { Aspirin } \\
\text { induced }\end{array}$ & $\begin{array}{c}\text { Group III } \\
\text { C. quadrangularis } \\
\text { treated }\end{array}$ & $\begin{array}{c}\text { Group IV } \\
\text { Cuadrangularis } \\
\text { +Aspirin }\end{array}$ \\
\hline $\begin{array}{l}\text { Lipid peroxides (nmol of TBARS/mg } \\
\text { protein) }\end{array}$ & $4.2 \pm 0.40$ & $9.1 \pm 0.78^{*}$ & $3.6 \pm 0.32^{\mathrm{NS}}$ & $4.6 \pm 0.39^{* *}$ \\
$\begin{array}{l}\text { Superoxide dismutase } \\
\quad \text { units/mg protein) }\end{array}$ & $361.7 \pm 10.3$ & $259.2 \pm 9.6^{*}$ & $369 \pm 11.6^{\mathrm{NS}}$ & $315.2 \pm 10.2^{* *}$ \\
$\begin{array}{l}\text { Catalase activity (nmol of } \mathrm{H}_{2} \mathrm{O}_{2} \\
\text { decomposed/min/mg protein) }\end{array}$ & $7.38 \pm 0.23$ & $4.85 \pm 0.17^{*}$ & $7.79 \pm 0.32^{\mathrm{NS}}$ & $6.87 \pm 0.21^{* *}$ \\
$\begin{array}{l}\text { Glutathione peroxidase (nmol of } \\
\quad \text { GSH utilized/s/mg protein) }\end{array}$ & $180 \pm 12.1$ & $51.7 \pm 4.8^{*}$ & $193 \pm 11.0^{\mathrm{NS}}$ & $176.1 \pm 14.4^{* *}$ \\
$\begin{array}{l}\text { Glutathione (nmol of GSH/mg } \\
\text { protein) }\end{array}$ & $77.1 \pm 5.8$ & $48.9 \pm 2.4^{*}$ & $69.4 \pm 3.7^{\mathrm{NS}}$ & $74.7 \pm 5.2^{* *}$ \\
$\begin{array}{l}\text { Glutathione-S-transferase }(\mu \mathrm{mol} \text { of } \\
\text { CDNB conjugated/min/mg protein) }\end{array}$ & $5.1 \pm 0.48$ & $2.96 \pm 0.17^{*}$ & $4.8 \pm 0.39^{\mathrm{NS}}$ & $3.99 \pm 0.28^{* *}$ \\
\hline
\end{tabular}

Values are mean \pm SD of 6 animals in each group. ${ }^{*} p<0.001$ as compared with Group I; ${ }^{* *} p<0.001$ as compared with Group II; NS, non-significant as compared with Group I.

Activities of antioxidative enzymes and concentration of TBARS are presented in Table 1. Levels of GSH, SOD, CAT, GPX, and GST showed a significant decline $(p<0.001)$ and increase in LPO content in aspirin administered rats, when compared with that of control rats (Group I). In Cissus quadrangularis pretreated rats (Group IV), the level of TBARS and antioxidative defense enzymes registered a near normal values when compared with ulcerated animals. 


\section{Discussion}

The efforts of scientists to understand how free radicals cause destruction as well as how antioxidants protect cells from damage could provide clues to treat or prevent disease [23]. The oxygen-derived free radicals in the process of aspirin induced injury may arise from a blockade of the physiological function of prostaglandin $\mathrm{E}_{2}$ and thromboxane $\mathrm{A}_{2}$ and in this way remove this cytoprotective effect; thus, the induction of ulcers is promoted [24].

Pretreatment with Cissus quadrangularis extract $(500 \mathrm{mg} / \mathrm{kg})$ given for 15 days resulted in healing of aspirin-induced gastric lesions. Gastric mucus is believed to play an important role in the defensive mechanism against gastric ulceration [25]. Oral pretreatment with the extract, although preventing ulceration, originated a limited increase in the quantity of gastric mucus.

The release of ALP has been suggested to play a role in tissue necrosis associated with various models of gastrointestinal ulceration [26]. The extract significantly reduced the ALP activity when compared with the aspirin control. MPO activity is used as an index of granulocyte content/infiltration in tissues [27]. The previous studies indicate that aspirin can promote increase in neutrophil adhesion to venular endothelium in vivo [28]. In addition, it has been reported that neutrophils mediate lipid peroxidation through the production of superoxide anions by the activated NADPH oxidoreductase in the cells [29]. TBARS and tissues associated MPO activity were measured in gastric mucosa as indices of lipid peroxidation and neutrophil infiltration [30]. The increase in TBARS and MPO activity after aspirin administration was significantly inhibited by treatment with Cissus quadrangularis. This suggests that Cissus quadrangularis may promote ulcer healing through additional mechanisms.

In the current study, the TBARS concentration was significantly reduced and antioxidative defence enzyme level increased in the Cissus quadrangularistreated groups compared with the aspirin induced group. This indicates that Cissus quadrangularis confers an equivalent anti-lipid peroxidation effect on the gastric tissue. Body et al. suggested that GSH levels were found to be decreased in gastric ulcer tissue [31]. Depletion of GSH will rendered enzymes (GPX and GST) inactive or less active. SOD content in gastric tissue is a point of controversy [32]. The protective action may be, due to the increase in the activities of SOD, CAT, GPX, and GST and in GSH content in the extract-treated group.

Reactive oxygen species production may damage cellular components; this damage, in part, is neutralized by mucosal antioxidant (ascorbic acid and $\beta$ carotene), which are good scavengers of free radicals [33]. Phytochemical studies carried out on Cissus quadrangularis revealed the presence of $\beta$-carotene, ascorbic acid, ketosteroids, triterpenoids [34], calcium, $\beta$-amyrin, and $\alpha$-amyrin [35]. The observed cytoprotective and antioxidative effect of Cissus quadrangularis is attributed to the presence of these antioxidative phytoconstituents.

In conclusion, it can be said that a possible healing action of Cissus quadrangularis could be due to antioxidative mechanism. Further studies are in progress to investigate the detailed mechanism of action of this potent herbal extract before clinical trials.

\section{References}

[1] Aruoma, O.I. and Guppet, S.L.: Antioxidant Methodology in vivo and in vitro Concepts, AOCS Press, Champaign, IL, pp. 41-172, 1997.

[2] Phian, G., Regillo, C., and Szabo, S.: Free radical and lipid peroxidation in ethanol or aspirin induced gastric mucosal injury. Dig. Dis. Sci., 32, 1395-1401, 1987.

[3] Shukla Mukherjee Sur, A. and Maiti, B.R.: Hepatoprotective effect of Swertia chirata on rat. Indian J. Exp. Biol., 35, 384-388, 1997.

[4] Prakash, A. and Faulds, D.: Rebaprazole. Drugs, 2, 55-56, 1998.

[5] Akthar, H.H. and Ahmed, K.U.: Antiulcerogenic evaluation of the methanolic extract of some indegenous medicinal plants of Pakistan in aspirin ulcerated rats. $J$. Ethnopharmacol., 46, 1-6, 1998.

[6] Kritikar, K.R. and Basu, B.D.: Indian Medicinal Plants (Third Revised and Enlarged ed.), ed. by Basu, L.M., Allahabad, Vol. 3, pp. 841-843, 2000.

[7] Anoop, A. and Jagdeesan, M.: Gastric and duodenal antiulcer and cytoprotective effect of Cissus quadrangularis Linn. variant II in rat. Nig. J. Nat. Prod. Med., 6, 1-7, 2002.

[8] Deka, D.K., Lahon, L.C., Saikia, J., and Mukit, A.: Effect of Cissus quadrangularis in acceleration healing process of experimentally fractured radius-ulna of dog; A experimental study. Indian J. Pharmacol., 26, 44-45, 1994.

[9] Singh, S.P., Misra, N., Dixit, K.S., Singh, N., and Kohli, R.P.: An experimental study of analgesic activity of Cissus quadrangularis. Indian J. Pharmacol., 2, 162263, 1984.

[10] Biswajit, M., Ray Chaudhuri, S.G., Arun, R., and Sandip Bandyopadhyay, K.: Effect of ethanol extract of Piper betle Linn. leaf on healing of NSAID-induced 
experimental ulcer-A novel role of free radical scavenging action. Indian J. Exp. Biol., 41, 311-315, 2003.

[11] Sata, N., Kawano, S., Tsuji, S., and Kamada, T.: Microvascular basis of gastric mucosal protection. $J$. Clin. Gastroenterol., 10, S13-S18, 1988.

[12] Szabo, S., Trier, J.S., and Brown, A.: A quantitative method for assessing the extent of experimental gastric erosions and ulcer. J. Pharmacol. Methods, 13, 59-66, 1985.

[13] Martin, M.J., Marhuenda, E., and Alarcon, L.: Esculine, ranitidine and carbenoxolone different modes of action on gastric mucosa. Gen. Pharmacol., 22, 10011004, 1991.

[14] Lowry, O.H., Rosebrough, N.J., and Fars, A.L.: Protein measurement with folin phenol reagent. J. Biol. Chem., 193, 265-278, 1951.

[15] Kind, P.R.N. and King, E.J.: Determination of serum alkaline phosphatase. Clin. Pathol., 7, 322-326, 1954.

[16] Suzuki, K., Sasagawa, S., Sakatani, T., and Fujikura, T.: Assay method for myeloperoxidase in human polymorphonuclear leukocytes. Anal. Biochem., 132, 345353, 1983.

[17] Ohkawa, H., Ohishi, N., and Yagi, K.: Assay for lipid peroxides in animal tissues by thiobarbituric acid reaction. Anal. Biochem., 95, 351-358, 1979.

[18] Misra, H.P. and Fridovich, I.: The role of superoxide anion in the autooxidation of epinephine and a simple assay for SOD. J. Biol. Chem., 247, 3170-3175, 1972.

[19] Luck, H.: Catalase, in Methods of Enzymatic Analysis, ed. by Bergmeyer, H.U., Academic Press, New York, London, pp. 885-888, 1963.

[20] Beautler, E. and Kelley, B.M.: The effect of sodium nitrate on red cell glutathione. Experientia, 19, 96-97, 1963.

[21] Paglia, D.E. and Valentaina, W.N.: Studies on the GSH and Glutathione characterization of erythrocyte GPX. J. Lab. Clin. Med., 70, 158-169, 1967.

[22] Habig, W.H., Pabst, M.J., and Jakoby, W.B.: Glutathione-S-transferase. The first enzymatic step in mercapturic acid formation. J. Biol. Chem., 240, 71130-71139, 1974.

[23] Pillai, K.S. and Pillai, C.: Antioxidant in health. Indian J. Physiol. Pharmacol., 46, 1-5, 2002.

[24] Steinmeyer, J.: Pharmacological basis for the therapy of pain and inflammation with NSAIDs. Arthritis Res., 2, 379-385, 2000.
[25] Martin, M.J., Alarcon de la Lastra, C., and Motilva, V.: Bases fisiopatologicas farmacologicas de la ulcera peptica, Secretariado de publications, Universidad de Sevilla Press, Sevilla, pp. 25-30, 1993.

[26] Obi, E., Meh, J.K., Orisakwe, O.E., Afonne, O.J., Ilondu, N.A., and Agbasi, P.U.: Investigation of the biochemical evidence for the antiulcerogenic activity of Synclisia scarbrida. Indian J. Pharmacol., 32, 381-383, 2000.

[27] Krawisz, J.F., Sharan, P., and Stenson, W.F.: Quantitative assay for acute intestinal inflammation based on MPO activity. Assessment of inflammation in rat and hamster models. Gastroenterology, 87, 1344-1350, 1984.

[28] Yoshida, N., Takemura, T., Granger, D.N., Anderson, D.C., Wolf, R.E., McIntive, L.V., and Kvietys, P.R.: Molecular determinations of aspirin-induced neutrophil adherence to endothelial cells. Gastroenterology, 105, 715-724, 1993.

[29] Zimmerman, J.J., Ceisielski, W., and Lewandoski, J.: Neutrophil-mediated phospholipid peroxidation assessed chromatography-mass spectroscopy. Am. J. Physiol., 273, C653-661, 1997.

[30] Naito, T., Takagi, T., Matsuyama, K., Yoshida, N., and Yoshikawa, T.: Pioglitazone, a specific PPAR- $\gamma$ ligand inhibits aspirin-induced gastric mucosal injury in rats. Aliment. Pharmacol. Ther., 15, 865-873, 2001.

[31] Body, S.C., Samasa, H.A., and Body, M.R.: Gastric glutathione depletion and acute ulcerogenesis by diethylamaleate given subcutaneously in rats. Life Sci., 28, 2987-2992, 1981.

[32] Mahendran, P. and Shyamala Devi, C.S.: The modulating effect of Garcinia combogia extracts on ethanol induced peroxidative damage in rats. Indian J. Pharmacol., 33, 87-91, 2001.

[33] Daneses, S., Candelli, M., Cremonini, F., and Stevens, T.R.: High oxygen free radicals generation in gastric mucosa infected by $H$. pylori cytotoxic strains (abstract). Gastroenterology, 118, A739-A743.

[34] Madan, M.G. and Ram, K.V.: Unsymmetric tetracyclic triterpenoid from Cissus quadrangularis. Phytochemistry, 29, 336-337, 1990.

[35] Udupa, K.N., Prasad, G., and Sen, S.P.: The effect of phytogenic anabolic steroid in the acceleration of fracture repair. Life Sci., 4, 317-327, 1965. 